\title{
Reductive Acid Leaching of Low Grade Manganese Ores
}

\author{
Alok Prasad Das ${ }^{1 *}$, Sarpras Swain ${ }^{1}$, Shriyanka Panda ${ }^{1}$, Nilotpala Pradhan ${ }^{2}$, Lala Behari Sukla ${ }^{2}$ \\ ${ }^{1}$ Centre of Biotechnology, Siksha "O” Anusandhan University, Bhubaneswar, India \\ ${ }^{2}$ Institute of Minerals and Materials Technology, Bhubaneswar, India \\ Email: *alok1503@gmail.com
}

Received September 12, 2012; revised October 12, 2012; accepted October 19, 2012

\begin{abstract}
Manganese recoveries from low-grade ores using organic acids as reducing agents were investigated in the present work. The acid leaching potential of both oxalic acid and citric acid were estimated. Manganese leaching amount were measured by using standard manganese curve and estimated by titration method. Effects of various acid concentrations on leaching efficiency were studied. The observed result suggested prominent manganese recovery of $66 \%$ by oxalic acid at $2 \mathrm{M}$ concentration whereas citric acid had less effect on leaching showing leaching percentage upto $40 \%$ in 6 days. Acid leaching of manganese ore with both the acids gave a comparative data stating that oxalic acid leached better than citric acid.
\end{abstract}

Keywords: Low Grade; Manganese ore; Oxalic Acid; Citric Acid; Leaching

\section{Introduction}

Manganese is the 12th most abundant element comprising about $0.10 \%$ of the earth's crust, with oxidation states existing in from -3 to +7 . The common chemical forms of manganese dioxide found naturally are +2 and +4 [1]. The oxides and peroxides of manganese are used for manufacturing metal alloys to increase hardness and for enhancement of alloy to be corrosion resistance and as a desulfurizing, deoxidizing element in various industrial processes [2,3]. Manganese plays an important role in steel production, preparation of dietary additives, chemical production, in battery cells industry [4,5]. Various studies have been carried out for leaching of low grade manganese ore using sulphuric acid and oxalic acid [6,7], nitric acid [8], hydrochloric acid and citric acid [9] as reducing agent and high leaching efficiency, but the basic problem are the high temperature, residual acid generation, associated cost and environmental pollution [10]. Implementation of new technique in commercial hydrometallurgical process to recover metals is based on the acid leaching technique, is basically governed by the following equations [11-13].

$$
\begin{gathered}
\mathrm{MnO}_{2}+\mathrm{C}_{2} \mathrm{H}_{2} \mathrm{O}_{4}+2 \mathrm{H}^{+} \rightarrow \mathrm{Mn}^{2+}+2 \mathrm{H}_{2} \mathrm{O}+2 \mathrm{CO}_{2} \\
\mathrm{MnO}_{2}+\mathrm{H}_{2} \mathrm{O}_{2}+2 \mathrm{H}^{+} \rightarrow \mathrm{Mn}^{2+}+2 \mathrm{H}_{2} \mathrm{O}+\mathrm{O}_{2} \\
\mathrm{MnO}_{2}+\mathrm{C}_{6} \mathrm{H}_{8} \mathrm{O}_{7}+2 \mathrm{H}^{+} \rightarrow \mathrm{Mn}^{2+}+\mathrm{H}_{2} \mathrm{O}+\mathrm{CO}_{2}
\end{gathered}
$$

${ }^{*}$ Corresponding author.
Our study investigated the leaching efficiency of citric acid $\left(\mathrm{C}_{6} \mathrm{H}_{8} \mathrm{O}_{7}\right)$ and oxalic acid $\left(\mathrm{C}_{2} \mathrm{H}_{2} \mathrm{O}_{4}\right)$ with different concentrations ( $0.1 \mathrm{M}, 0.25 \mathrm{M}, 0.5 \mathrm{M}, 1 \mathrm{M}, 2 \mathrm{M})$ and low grade manganese ore with pulp density $2 \%$ for 6 days.

\section{Materials and Methods}

\subsection{Sample Collection}

The low grade manganese ore was collected from different Ferro-manganese mines, Keonjhar district in Odisha, India. All pieces were ground to smaller particles using ball mill. The physio-chemical properties of samples were characterized. The presence of other heavy metals was estimated by Atomic Absorption Spectroscopy method. The Mn concentration was calculated by titration method.

\subsection{Leaching Procedure}

The leaching experiment was done in $200 \mathrm{ml}$ flask with citric acid and oxalic acid individually with different concentration i.e. $0.1 \mathrm{M}, 0.25 \mathrm{M}, 0.5 \mathrm{M}, 1 \mathrm{M}$, and $2 \mathrm{M}$ of each acid in separate flasks. The Manganese ore leaching was carried out with pulp density of ore $2 \%, 150 \mathrm{rpm}$ at room temperature. The experiment was carried out for 6 days and reading of percentage of leaching was noted at every 3 days interval by titrating with EDTA. To calculate leaching percentage the standard graph was prepared. 


\subsection{Standard Graph Preparation for Mn Concentration}

As from various experimental data it has been reported that $3.565 \mathrm{gm}$ of $\mathrm{MnCl}_{2}$ contain $1 \mathrm{gm}$ of $\mathrm{Mn}$. From this data separate solution was prepared which contain different amount of Mn concentration i.e. $0.5 \mathrm{mg} / \mathrm{ml}, 1 \mathrm{mg} /$ $\mathrm{ml}, 1.5 \mathrm{mg} / \mathrm{ml}$ up to $5 \mathrm{mg} / \mathrm{ml}$ and titrated with $0.01 \mathrm{M}$ of EDTA. Graph was plotted by taking concentration of Mn in $\mathrm{X}$-axis and Burette reading in $\mathrm{Y}$-axis. By using that graph, Mn concentration in solution was calculated and leaching efficiency was measured.

\section{Results \& Discussion}

Our study on acid leaching of Manganese ore with Oxalic acid and Citric acid gives a comparative data about leaching, which shows that oxalic acid has a better leaching potential than citric acid. Efficiency of acid leaching can be calculated by using standard graph as shown in Figure 1.

\subsection{Effect of Oxalic Acid on Manganese Leaching}

Percentages of leaching were calculated with $\mathrm{Mn}^{2+}$ standard graph (Figure 1) and with respect to that graph, citric acid and oxalic acid leaching efficiency were calculated. Oxalic acid leaching of ore at $2 \mathrm{M}$ concentration was $66 \%$ and decrease in concentration, i.e. at $1 \mathrm{M}, 0.5$ M, $0.25 \mathrm{M}, 0.1 \mathrm{M}$ concentration leaching were $52 \%$, $43 \%, 18 \%, 15 \%$ respectively (Figure 2).

\subsection{Effect of Citric Acid on Manganese Leaching}

Citric acid leaching was high at $2 \mathrm{M}$ about $40 \%$ after 6 days and decrease in concentration i.e. at $1 \mathrm{M}, 0.5 \mathrm{M}$, $0.25 \mathrm{M}, 0.1 \mathrm{M}$ concentration leaching were found to be $29 \%, 18 \%, 10 \%, 7 \%$ respectively (Figure 3 ).

Our study emphasizes on the leaching of low grade manganese ores with minimal concentrations of both the organic acids. Acid produced by the biological species are of $0.5 \mathrm{M}$ to $1 \mathrm{M}$ concentration and shows better leaching capacity without any hazardous effect, therefore the acid concentration levels were taken as per the natural concentration. Optimal condition for the leaching experiments were $35^{\circ} \mathrm{C}$ temperature, $-150 \mu \mathrm{m}$ particle size and $2 \%$ pulp density and found that leaching of manganese obeys the linear relationship with concentration i.e. increase in concentration increases the acid leaching efficiency. The result suggested that oxalic acid have greater leaching capacity than citric acid due to its affinity to bind with $\mathrm{Mn}$ and act as the reducing agent by providing $\mathrm{H}^{+}$ion [2]. Oxalic acid has high affinity toward $\mathrm{Mn}$ and form Mn-oxalate complexes which leach out manganese from the ore [2].

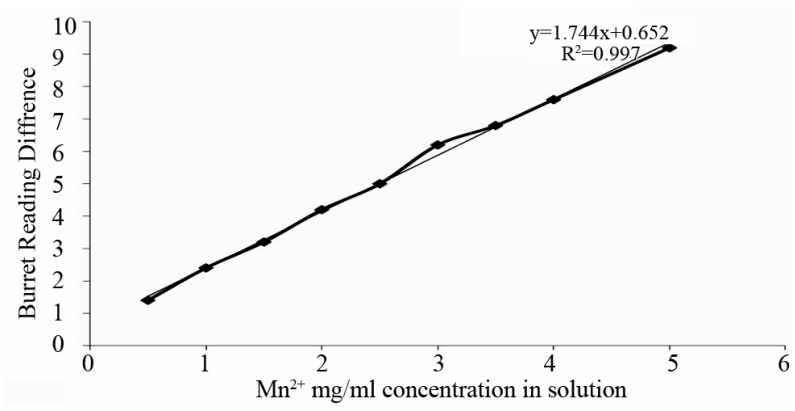

Figure 1. Concentration of $\mathrm{Mn}^{2+}$ in terms of $\mathrm{mg} / \mathrm{ml}$ with respect to burette reading difference to calculate Mn concentration of other reaction taking this as standard.

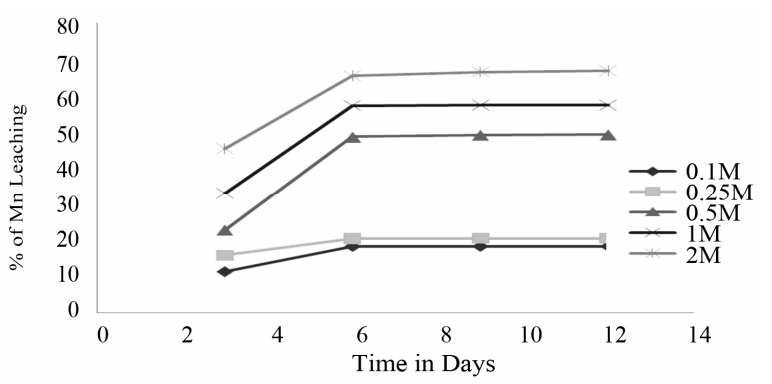

Figure 2. Effect of Oxalic acid at different Concentration on Mn ore.

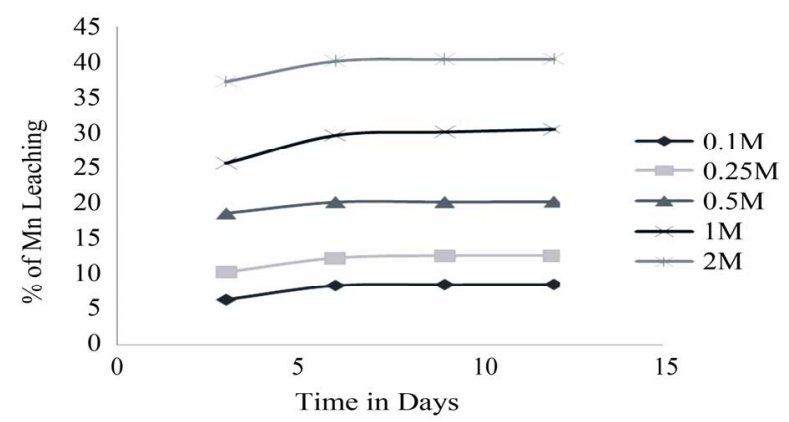

Figure 3. Effect of Citric acid at different concentration on Mn ore.

$$
\begin{aligned}
& \mathrm{MnO}_{2}+2 \mathrm{H}_{2} \mathrm{C}_{2} \mathrm{O}_{4} \\
\rightarrow & \mathrm{MnC}_{2} \mathrm{O}_{4}+2 \mathrm{CO}_{2}+2 \mathrm{H}_{2} \mathrm{O} \\
\rightarrow & \mathrm{Mn}^{2+}+2 \mathrm{H}_{2} \mathrm{O}+4 \mathrm{CO}_{2}
\end{aligned}
$$

Citric acid act as only reducing agent with less efficiency but it don't bind with Mn forming complexes. Therefore an advantage of oxalic acid over citric acid is the ability to form complex with Mn which increases the leaching capacity of manganese.

\section{Conclusion}

Our study emphasizes on the leaching of manganese by organic acids at minimal amount of acid at normal condition. The acid leaching of low grade manganese ore showed that with the increase in acid concentration upto 
$2 \mathrm{M}$ the leaching efficiency increases to $66 \%$ for oxalic acid and $40 \%$ for citric acid. Recovery of Manganese increases with oxalic acid whereas in case of citric acid it is lower. At different concentration of oxalic acid from $0.1 \mathrm{M}$ to $2 \mathrm{M}$, the efficiency of leaching varies from $11 \%$ to $66 \%$ whereas in case of citric acid it ranges from $8 \%$ to $40 \%$. Comparative study between citric acid and oxalic acid were examined and found to be effective on leaching and illustrated the fact that the effect of oxalic acid was high on manganese leaching due to its role as reducing agent and affinity to bind with manganese as a complex Units.

\section{REFERENCES}

[1] A. P. Das, L. B. Sukla, N. Pradhan and S. Nayak, "Manganese Biomining: A Review,” Bioresource Technology, Hydrometallurgy, Vol. 102, No. 16, 2011, pp. 7381-7387.

[2] A. P. Das, L. B. Sukla and N. Pradhan, "Microbial Recovery of Manganese Using Staphylococcus Epidermidis," International Journal of Nonferrous Metallurgy, Vol. 1, No. 2, 2012, pp. 9-12.

[3] J. K. Magnuson and L. L. Lasure, "Organic Acid Production by Filamentous Fungi,” Plenum Publishers, New York, 2004, pp. 307-340.

[4] M. Gharabaghi, M. Irannajad and M. Noaparast, “A Review of the Beneficiation of Calcareous Phosphate Ores Using Organic Acid Leaching,” Hydrometallurgy, Vol. 103, No. 1-4, 2010, pp. 96-107. doi:10.1016/j.hydromet.2010.03.002

[5] P. K. Sahoo and R. K. Srinivasa, "Sulphating-Roasting of Low Grade Manganese Ore: Optimisation by Factorial Design,” International Journal of Mineral Processing, Vol. 25, No. 1-2, 1989. pp. 147-152. doi:10.1016/0301-7516(89)90061-6

[6] R. N. Sahoo, P. K. Naik and S. C. Das, "Leaching of Manganese from Low-Grade Manganese Ore Using Oxalic
Acid as Reductant in Sulphuric Acid Solution,” Hydrometallurgy, Vol. 62, 2001, pp. 157-163. doi:10.1016/S0304-386X(01)00196-7

[7] F. Pagnanelli, G. Furlani, P. Valentini, F. Vegliò and L. Toro, "Leaching of Low-Grade Manganese Ores by Using Nitric Acid and Glucose: Optimization of the Operating Conditions," Hydrometallurgy, Vol. 75, No. 1-4, 2004, pp. 157-167. doi:10.1016/j.hydromet.2004.07.007

[8] E. Y. Lee, "Leaching of Mn, Co, and Ni from Manganese Nodules Using an Aerobic Bioleaching Method,” Journal of Bioscience and Bioengineering, Vol. 92, 2001, pp. 354-359.

[9] S. Kukrer, N. O. Yigit, G. Civelekoglu and M. Kitis, "Acidic Leaching and Precipitation of Zinc and Manganese from Spent Battery Powders Using Various Reductants,” Journal of Hazardous Materials, Vol. 173, No. 1-3, 2010, pp. 137-143. doi:10.1016/j.jhazmat.2009.08.063

[10] G. M. Gadd, "Fungal Production of Citric and Oxalic Acid: Importance in Metal Speciation, Physiology and Biogeochemical Processes” Advances in Microbial Physiology, Vol. 41, 1999, pp. 47-92. doi:10.1016/S0065-2911(08)60165-4

[11] B. Ghafarizadeh, F. Rashchi and E. Vahidi, "Recovery of Manganese from Electric Arc Furnace Dust of Ferromanganese Production Units by Reductive Leaching,” Minerals Engineering, Vol. 24, No. 2, 2011, pp. 174-176. doi:10.1016/j.mineng.2010.11.003

[12] H. F. Su, Y. X. Wen, F. Wang, Y. Y. Sun and Z. F. Tong, "Reductive Leaching of Manganese from Low-Grade Manganese Ore in $\mathrm{H}_{2} \mathrm{SO}_{4}$ Using Cane Molasses as Reductant,” Hydrometallurgy, Vol. 93, No. 3-4, 2008, pp. 136-139. doi:10.1016/j.hydromet.2008.01.001

[13] W. Zhang and C. Y. Cheng, "Manganese Metallurgy Review. Part I: Leaching of Ores/Secondary Materials and Recovery of Electrolytic/Chemical Manganese Dioxide,” Hydrometallurgy, Vol. 89, 2007, pp. 137-159. doi:10.1016/j.hydromet.2007.08.0 